\title{
Diagnosis, management, histology and genetics of sporadic primary hyperparathyroidism: old knowledge with new tricks
}

\author{
Maria Mizamtsidi', Constantinos Nastos², George Mastorakos ${ }^{3}$, Roberto Dina4 ${ }^{4}$, loannis Vassiliou², \\ Maria Gazouli ${ }^{5}$ and Fausto Palazzo 6 \\ 1Department of Endocrinology, Diabetes and Metabolism, Hellenic Red Cross Hospital, Athens, Greece \\ ${ }^{2}$ Second Department of Surgery, Endocrine Surgery Unit, Aretaieion University Hospital, National and Kapodistrian University of Athens, Athens, Greece \\ ${ }^{3}$ Unit of Endocrinology, Diabetes and Metabolism, Aretaieion University Hospital, National and Kapodistrian University of Athens, Athens, Greece \\ ${ }^{4}$ Department of Pathology, Hammersmith Hospital, Imperial College Healthcare NHS Trust, London, UK \\ ${ }^{5}$ Department of Basic Medical Sciences, Laboratory of Biology, School of Medicine, National and Kapodistrian University of Athens, Athens, Greece \\ ${ }^{6}$ Department of Thyroid and Endocrine Surgery, Imperial College London, London, UK
}

Correspondence should be addressed to M Mizamtsidi: maria.mizamtsidi@gmail.com

\begin{abstract}
Primary hyperparathyroidism (pHPT) is a common endocrinopathy resulting from inappropriately high PTH secretion. It usually results from the presence of a single gland adenoma, multiple gland hyperplasia or rarely parathyroid carcinoma. All these conditions require different management, and it is important to be able to differentiate the underlined pathology, in order for the clinicians to provide the best therapeutic approach. Elucidation of the genetic background of each of these clinical entities would be of great interest. However, the molecular factors that control parathyroid tumorigenesis are poorly understood. There are data implicating the existence of specific genetic pathways involved in the emergence of parathyroid tumorigenesis. The main focus of the present study is to present the current optimal diagnostic and management protocols for pHPT as well as to review the literature regarding all molecular and genetic pathways that are to be involved in the pathophysiology of sporadic pHPT.
\end{abstract}

\author{
Key Words \\ - sporadic primary \\ hyperparathyroidism \\ - adenoma \\ - hyperplasia \\ - multiple gland disease \\ - carcinoma \\ - genetic and molecular \\ pathways
}

\section{Introduction}

Hyperparathyroidism is characterized by hypersecretion of parathyroid hormone (PTH) from the parathyroid glands. According to the cause of hypersecretion, hyperparathyroidism can be classified as primary, secondary or tertiary. Primary hyperparathyroidism (pHPT) is a common endocrinopathy resulting from inappropriately high PTH secretion from one or more enlarged parathyroid glands $(1,2)$. Secondary hyperparathyroidism usually results from low vitamin D levels or renal failure, while the tertiary form of the disease occurs when there is autonomous hypersecretion from one or more affected glands, despite resolution of secondary hyperparathyroidism (2).
The diagnosis may extend from normocalcemia accompanied by elevated PTH levels to hypercalcemia accompanied by elevated or inappropriately normal PTH levels. The incidence of pHPT is estimated to be 3:1000 in the general population and most cases are sporadic (3). However, $5-10 \%$ of the patients may be associated with syndromic and hereditary disease, like multiple endocrine neoplasia type 1 (MEN1), type 2A (MEN2A), type 4 (MEN4) and hyperparathyroidism jaw-tumor syndrome (HPT-JS) or the non-syndromic familial form of the disease, the familial isolated primary hyperparathyroidism (FIHP) $(2,4)$.

Almost $90 \%$ of the patients are found to have sporadic, non-familial and non-syndromic disease (4). Sporadic

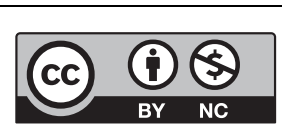

This work is licensed under a Creative Commons Attribution-NonCommercial 4.0 International License. 
pHPT is usually caused by a single gland adenoma $(85 \%$ of patients), but may also be caused by hyperplasia of all four glands (10\%), double adenomas (2-5\%) or rarely parathyroid carcinomas $(<1 \%)(1,2)$. The wide spectrum of disease presentation is very important as different management strategies are in demand.

There are data implicating specific genetic pathways in the emergence of adenomas, hyperplasias and carcinomas $(5,6)$, although it seems that epigenetic changes could also participate actively in parathyroid tumorigenesis $(7,8)$. The main focus of the present study is to present the current optimal diagnostic and management protocols for pHPT as well as to review the literature regarding all molecular and genetic pathways that are involved in the pathophysiology of sporadic pHPT.

\section{Diagnosis of pHPT}

The simultaneous presence of persistent hypercalcemia and elevated or inappropriately normal PTH levels, makes the diagnosis of pHPT likely $(9,10,11)$, but not definite and alternative benign states such as familial hypocalciuric hypercalcemia (FHH) should be excluded (12). FHH is an autosomal-dominant disorder resembling pHPT, which is not cured by surgery (12). The presentation of both disorders may be confusing and the establishment of the diagnosis requires a careful and detailed workup.

Although the clinical presentation of patients with pHPT is heterogeneous and the associated symptoms may overlap with those of aging and disease (10), usually patients with symptomatic pHPT have overt signs and symptoms; however, the definition of symptomatic disease is still evolving. Patients with asymptomatic pHPT have no disease-specific symptoms but the diagnosis is always biochemical and well stated in the latest published guidelines on the diagnosis and management of the disease $(10,11,13)$.

Another aspect of the disease is normocalcemic pHPT, which is an abnormality of the relationship between calcium and PTH. Normocalcemic pHPT presents with calcium levels within the normal range and the diagnosis could be revealed, with the use of calcium loading test: When an oral (or I V) load of $1 \mathrm{~g}$ elemental calcium or calcium gluconate infusion is given, serum ionized calcium concentration increases to supranormal values, and in normal individuals, a PTH suppression is expected $(14,15)$. However, in patients with normocalcemic pHPT, only a minimal reduction in serum PTH concentration is seen (14). The reactivity of PTH to calcium loading could

$$
\text { http://www.endocrineconnections.org }
$$

be used to establish the diagnosis of normocalcemic pHPT $(14,15,16,17,18,19,20)$, as PTH and calcium levels may become inappropriate only after the calcium load.

It is of great importance to adjust the total serum calcium levels not only for albuminemia but also for serum protein levels, as hyper- or hypo-proteinemia could lead to false diagnosis (9). If the adjusted total serum calcium level is normal, but PTH levels are elevated, then the ionized calcium levels could be measured, as pHPT could present with normal total but elevated ionized calcium levels $(9,11)$. The ionized calcium measurement should be performed in a pH-stable environment, as acidosis or alkalosis could cause respectively elevated or suppressed levels of ionized calcium (21). However, this measurement is of high cost and not widely available (11).

For the diagnosis of pHPT, other states that mimic pHPT should be excluded, such as FHH or medication intake (hydrochlorothiazide or lithium) (11). For the exclusion of $\mathrm{FHH}$, calcium to creatinine clearance ratio (CaCrCR) is used and if the ratio is greater than 0.02, then the presence of $\mathrm{FHH}$ is unlikely, provided that the patient has normal renal function, there is no severe calcium or vitamin D deficiency and the patient is not under treatment with loop diuretics (11). In the presence of a $\mathrm{CaCrCR}<0.02$, the CASR gene analysis may be helpful in establishing the diagnosis of FHH (22). However, it should be taken into account that there is high risk of diagnostic confusion between FHH and pHPT, as CaCrCR can greatly overlap between both hypercalcemic states (12). In addition, there are other genes involved in $\mathrm{FHH}$, defining three different FHH subtypes (12). FHH type 1 is due to a mutation of the CASR gene, while FHH type 2 and 3 are caused by mutations of GNA11 and AP2S2 genes respectively (12). Moreover, another clinical entity that may raise diagnostic dilemmas has been recognized, 'The Genetically Negative FHH', which involves patients with an $\mathrm{FHH}$ phenotype (hypercalcemia, normal or slightly elevated PTH), no genetic abnormality of CASR, GNA11 and AP2S1 genes, at least one family member with the same phenotype and/or failure of surgical removal of parathyroid gland(s) to correct hypercalcemia (12).

Secondary causes for PTH elevation must be meticulously excluded as they mimic normocalcemic $\mathrm{pHPT}$ $(9,11,23)$, like malabsorption syndromes, hypercalciuria and certain medications such as bisphosphonates, denosumab and loop diuretics. The presence of pHPT in children and young adults may be associated with the hereditary/syndromic forms of pHPT; however, analyzing the hereditary forms of pHPT is beyond the scope of the present review.

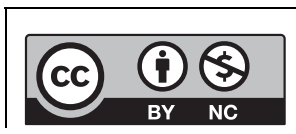

This work is licensed under a Creative Commons Attribution-NonCommercial 4.0 International License. 


\section{Localization of the disease}

Although the diagnosis of pHPT is biochemical, the localization-imaging studies may reveal the gland or glands that are affected. Parathyroid imaging is not a diagnostic procedure and is advised only if parathyroidectomy (PTx) is planned (9). Once the PTx is decided, localization studies are the next step in order to identify the affected gland(s). The most common imaging techniques are ${ }^{99 m}$ Tc-sestamibi scintigraphy, ultrasound and computed tomography (CT) (24). Parathyroid adenomas or multiple gland disease are not always identified, and thus, parathyroid imaging studies can be negative, but this should not preclude PTx, in specialized and experienced endocrine surgeons' hands (11).

\section{9mTc-sestamibi scintigraphy}

This imaging technique is based on the preferential uptake of ${ }^{99 \mathrm{~m}} \mathrm{Tc}$-sestamibi by the mitochondria-rich areas in parathyroid adenomas and hyperplasias (11). Normally, ${ }^{99 m}$ Tc-sestamibi uptake is also observed in the thyroid, salivary glands, thymus, mammary gland during lactation, liver and bone marrow. This technique is sensitive (90\%) and accurate (97.2\%) for pHPT. There are two different options for ${ }^{99 \mathrm{~m}} \mathrm{Tc}$-sestamibi technique, the single isotope washout scintigraphy and the two isotopes-subtraction scintigraphy ${ }^{99 \mathrm{~m}} \mathrm{Tc}-\mathrm{sestamibi}$ and $\left.{ }^{123} \mathrm{I}\right)$. In the single isotope technique, delayed washout is observed in well-defined areas indicating the parathyroid hyperfunctioning lesion. In the two-isotope technique, there is uptake of ${ }^{99} \mathrm{~m} T c-s e s t a m i b i$ and ${ }^{123} \mathrm{I}$ by the thyroid and uptake of ${ }^{99 \mathrm{~m}} \mathrm{Tc}$-sestamibi only by the parathyroids. The subtraction images may reveal the parathyroid adenoma or multiple gland disease. The addition of single-photon emission tomography (SPECT) alone or in combination with low-dose CT usually improves the localization of the parathyroid lesion (11).

\section{Ultrasound}

Normal parathyroid glands are usually not detected by ultrasound. Parathyroid adenomas are usually seen as round or oval, hypoechogenic structures, contrasting the hyperechogenic thyroid tissue (11). Large parathyroid adenomas may involve calcifications and cysts (11). Ultrasound is most useful in identifying adenomas close to the thyroid gland (11). Ultrasound may be useful as an additional study to confirm the localization of a parathyroid adenomas identified by ${ }^{99 \mathrm{~m}} \mathrm{Tc}-\mathrm{sestamibi}$ (11).

$$
\text { http://www.endocrineconnections.org }
$$

\section{Magnetic resonance imaging (MRI)}

MRI is used less commonly due to its lower sensitivity (50\%); however, it is the imaging of choice for pregnant patients. The adenomas appear as a soft tissue mass with high signal intensity on T2-weighted frames, but low to moderate in T1-weighted frames (11). The signal intensity of the adenoma is enhanced after gadolinium injection on T1-weighted frames, compared to normal thyroid tissue. Lymph nodes may have the same appearance (11).

\section{Computed tomography}

CT is useful in localizing ectopic mediastinal parathyroid glands with a sensitivity of approximately $46-87 \%$. Another technique that is being used recently with high sensitivity is the $4 \mathrm{D}-\mathrm{CT}$, with time being the fourth dimension. CT allows rapid assessment of the glands but has higher cost, exposure to radiation and requires iodinated contrast agents (11).

\section{${ }^{11} \mathrm{C}-$ Methionine PET/CT scintigraphy}

This imaging method is not widely available and is rarely used due to its high cost. It is based on the uptake and incorporation of the amino acid methionine in the PTH molecule during its synthesis (11).

\section{Selective venous sampling with PTH measurements}

This technique is mainly used in cases of unsuccessful surgery or reoperations. It requires an experienced angiographer, and it is expensive but has a high sensitivity, almost $75 \%$ when comparing with ${ }^{99 \mathrm{~m}}$ Tc-sestamibi-SPECT (30\%). When all non-invasive techniques have failed in revealing the lesion, then selective venous sampling is the imaging of choice in reoperation cases (11).

\section{Management of pHPT}

The only definitive treatment for pHPT is PTx. Patients with symptomatic pHPT should be advised to undergo surgery, unless serious contraindications or significant comorbidities exist. However, surgical treatment can also be offered to the asymptomatic patients who meet the guideline criteria (age $<50$, serum calcium $>1 \mathrm{mg} / \mathrm{dL}$ of the upper limit of the reference interval, BMD $T$-score $\leq-2.5$ at the lumbar spine, femoral neck, the total hip, the distal $1 / 3$ radius or low-energy fracture, glomerular 
Table 1 Evolution of guidelines criteria for surgical management of asymptomatic pHPT throughout the years 1990-2016.

\begin{tabular}{|c|c|c|c|c|c|}
\hline Year & $1990^{a}$ & $2002^{b}$ & $2008^{c}$ & $2014^{d}$ & $2016^{e}$ \\
\hline Age & $<50$ & $<50$ & $<50$ & $<50$ & $<50$ \\
\hline Calcium levels & $\begin{array}{l}\text { 1-1.6 mg/dL the } \\
\text { upper limit or } \\
\text { life-threatening } \\
\text { hypercalcemia }\end{array}$ & $\begin{array}{c}>1 \mathrm{mg} / \mathrm{dL} \text { the } \\
\text { upper limit }\end{array}$ & $\begin{array}{c}>1 \mathrm{mg} / \mathrm{dL} \text { the } \\
\text { upper limit }\end{array}$ & $>1 \mathrm{mg} / \mathrm{dL}$ the upper limit & $\begin{array}{l}>1 \mathrm{mg} / \mathrm{dL} \text { the upper limit or } \\
>0.12 \mathrm{mmol} / \mathrm{L} \text { for } \mathrm{Ca}^{2+}\end{array}$ \\
\hline Renal function & $\begin{array}{l}\text { eGFR reduction } \\
>30 \%\end{array}$ & $\begin{array}{l}\text { eGFR reduction } \\
>30 \%\end{array}$ & eGFR $<60 \mathrm{~mL} / \mathrm{min}$ & $\mathrm{eGFR}<60 \mathrm{~mL} / \mathrm{min}$ & $\mathrm{eGFR}<60 \mathrm{~mL} / \mathrm{min}$ \\
\hline $\begin{array}{l}\text { Urine calcium } \\
\text { excretion }\end{array}$ & $>400 \mathrm{mg} / \mathrm{dL}$ & $>400 \mathrm{mg} / \mathrm{dL}$ & $\begin{array}{l}24 \mathrm{~h} \text { urine for } \\
\text { calcium not } \\
\text { recommended }\end{array}$ & $>400 \mathrm{mg} / \mathrm{dL}$ & $>400 \mathrm{mg} / \mathrm{dL}$ \\
\hline Osteoporosis & $\begin{array}{l}\text { Z-Score }<-2.0 \\
\text { (forearm) }\end{array}$ & $\begin{array}{l}T \text {-Score }<-2.5 \\
\text { (any site) }\end{array}$ & $\begin{array}{l}T \text {-Score }<-2.5 \\
\text { (any site) and/or } \\
\text { fragility fracture }\end{array}$ & $\begin{array}{l}T \text {-Score }<-2.5 \text { (lumbar } \\
\text { spine, total hip, } \\
\text { femoral neck, or distal } \\
\text { radius) and/or fragility } \\
\text { fracture diagnosed by } \\
\text { imaging }\end{array}$ & $\begin{array}{l}T \text {-Score } \leq-2.5 \text { (lumbar spine, } \\
\text { femoral neck, total hip, or } \\
\text { the } 1 / 3 \text { radius) for } \\
\text { postmenopausal women or } \\
\text { males }>50 \text { years. A prevalent } \\
\text { low-energy fracture, which } \\
\text { requires a routine } X-\text {-ray of } \\
\text { the thoracic and lumbar } \\
\text { spine (or vertebral fracture } \\
\text { assessment by DXA) }\end{array}$ \\
\hline Other & $\begin{array}{l}\text { Kidney stones } \\
\text { detected by } \\
\text { abdominal } \\
\text { radiograph }\end{array}$ & & & $\begin{array}{l}\text { Presence of nephroli- } \\
\text { thiasis or nephrocalci- } \\
\text { nosis by X-ray, } \\
\text { ultrasound, or CT }\end{array}$ & $\begin{array}{l}\text { Presence of nephrolithiasis, } \\
\text { nephrocalcinosis or increased } \\
\text { stone formation risk }\end{array}$ \\
\hline
\end{tabular}

aDiagnosis and management of asymptomatic primary hyperparathyroidism. National Institutes of Health Consensus Development Conference. October 29-31, 1990. Consensus Statement. 1990 Oct 29-31;8 (7):1-18; bilezikian JP et al., 2002 Summary Statement from a Workshop on Asymptomatic Primary Hyperparathyroidism: A Perspective for the 21st Century. J Bone Miner Res 17: Suppl 2: N2-11; 'Bilezikian JP, Khan AA, Potts JT Jr, 2009 Guidelines for the management of asymptomatic primary hyperparathyroidism: summary statement from the third international workshop. J Clin Endocrinol Metab 94 :

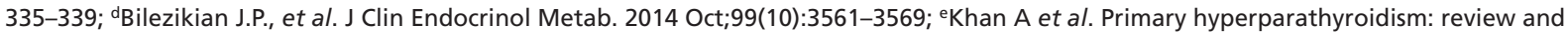
recommendations on evaluation, diagnosis, and management. A Canadian and international consensus. Osteoporosis International 2017; 28:1-19. eGRF, estimated glomerular filtration rate.

filtration rate (GFR) of $<60 \mathrm{~mL} / \mathrm{min}$, nephrocalcinosis, renal stones or high stone risk). Table 1 presents the latest guidelines in comparison with older ones for the management of asymptomatic pHPT. Data from cohort studies demonstrated reductions in the risk of all fractures and renal stone formation post-PTx $(25,26,27,28)$.

Cure rates in specialized endocrine surgeons hands exceed 95\%, with complications rates as low as 1-3\% (29). In patients with a single adenoma ( $85 \%$ of patients), surgery can be curative. In the $15 \%$ of patients with multiple gland disease, the recurrence rate is higher and requires a subtotal PTx. Parathyroid carcinoma is rarely $(<1 \%)$ the cause of pHPT. If a patient is suspicious for carcinoma (tumor size $>3 \mathrm{~cm}$, palpable mass, and serum calcium $>14 \mathrm{mg} / \mathrm{dL}$ ) (30), en bloc resection of the ipsilateral thyroid lobe and any invaded tissues should be performed (29).

PTx benefits may also include cardiac and vascular function (31), neurologic and gastrointestinal health and most patients report a general clinical improvement (29). The complications of PTx are rare and may include failure to cure the disease by not finding the affected gland(s), persistence or recurrence of the disease, recurrent laryngeal nerve damage, damage in the normal parathyroid glands, bleeding or hematoma and infection. Patients should be advised to maintain unrestricted calcium intake and sufficient vitamin D levels before surgery in order to avoid hungry bone syndrome.

Successful preoparative localization of a parathyroid adenoma is a good indication for minimally invasive parathyroidectomy in non-syndromic patients with sporadic pHPT. The benefits of this technique are reduced operative time, outpatient surgery, reduced costs and fewer complications (29). As suggested by the latest guidelines, if preoperative imaging has not identified a parathyroid adenoma or hyperplasia or if familial disease is highly suspected, bilateral neck exploration PTx is preferred (29). A bilateral neck exploration and subtotal PTx is usually performed in syndromic patients or in patients with lithium-induced pHPT (11). The minimally invasive approach can be extended to a bilateral neck exploration if an adenoma cannot be found or if the patient has unsuspected multiglandular disease. Multiglandular pHPT may not be excluded before surgery and is seen in almost http://www.endocrineconnections.org

https://doi.org/10.1530/EC-17-0283 (c) 2018 The authors Published by Bioscientifica Ltd
This work is licensed under a Creative Commons Attribution-NonCommercial 4.0 International License. 
one in ten patients with sporadic pHPT (29), and in these cases, bilateral neck exploration is mandatory.

Patients with asymptomatic pHPT who do not meet guidelines for surgery or are unable or unwilling to undergo PTx may be offered monitoring, with unrestricted calcium intake and maintenance of sufficient vitamin D levels. Antiresorptive treatment (bisphosphonates or hormone replacement therapy) should be considered in patients with osteoporosis or in the presence of fragility fractures in patients who are unable or unwilling to undergo PTx (11).

Another option is cinacalcet, a calcimimetic agent, which lowers serum calcium and PTH by increasing the sensitivity of the CaSR to extracellular calcium, thereby decreasing serum PTH and reducing the renal tubular reabsorption of calcium. With cinacalcet, serum calcium normalizes in 70-80\% of patients with pHPT, but fails to normalize PTH in about $50 \%$ of patients. European Medicines Agency (EMA) and The Food and Drug Administration agency of the United States (FDA) have approved the use of cinacalcet for the treatment of secondary hyperparathyroidism in patients with chronic kidney disease (CKD) on dialysis, for treating hypercalcemia in patients with parathyroid carcinoma and for the treatment of severe hypercalcemia in patients with primary HPT who are unable to undergo parathyroidectomy. The main disadvantage of this cinacalcet is its high cost and a high incidence of adverse reactions, mainly from the gastrointestinal system. It is a useful option in symptomatic patients in whom the disease cannot be controlled by surgical intervention or in circumstances where surgery is contraindicated and in patients with unresectable parathyroid cancer (11). This drug also does not improve bone mineral density or lower biochemical markers of bone turnover (32). There are not sufficient data on its effects on hypercalcemic symptoms, renal stones or quality of life. Treatment with cinacalcet is responsible for urinary calcium excretion, either by reduction of tubular calcium reabsorption via the reduction of PTH level or via a direct effect on the calcium sensor receptor located in the upper thick ascending limb of the loop of Henle. However, recent studies reported that patients carrying the rs1042636 polymorphism of the calcium-sensing receptor gene respond more sensitively to cinacalcet and have a higher risk of calcium stone formation (33). Data with medical therapy currently is short term and insufficient to justify medical therapy as an alternative to surgery (11).

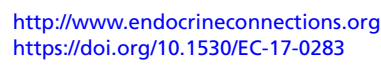

\section{Histopathological features of parathyroid neoplasms}

The histological distinction between the various forms of primary hyperparathyroidism is challenging as the differential diagnosis between a single adenoma and multiple gland disease is difficult. When in sporadic pHPT only one gland is affected, it usually bears only one adenoma. However, when multiple glands are involved, they may present a range of pathology from diffuse hyperplasia to asymmetric hyperplasia or multiple adenomas. Moreover, the histological diagnosis of parathyroid cancer can be challenging and in some cases diagnosis can only be done following revelation of distant metastases. However, there are some pathological features that are used for the histological classification of the tumors, and these features are being analyzed.

\section{Primary adenoma}

The incidence of parathyroid adenomas in sporadic pHPT is estimated to be $85-90 \%$ (2). They are usually single, while multiple affected glands account for $20 \%$ of the cases and carcinomas for $<1 \%$ of cases (34). 'Double' or 'multiple' adenomas may at least in some cases alternatively represent multigland hyperplasia, presenting asymmetrically and sometimes asynchronously (34).

Most adenomas are composed of chief cells, a small percentage may be oxyphilic, large clear cell adenomas or rarely 'water-clear' adenomas or lipoadenomas (34, 35). Typical parathyroid adenomas are surrounded by a fibrous capsule; however, microadenomas (weighting $<0.1 \mathrm{~g}$ ) are usually non-encapsulated. A rim of normal parathyroid tissue is often present at the periphery of adenomas, although this feature may not be always present. The component cells may be arranged in cords, nests, sheets and follicles and may arrange around blood vessels. The round and densely stained nuclei are larger than those present in the non-neoplastic parathyroid tissue. The nuclei are also hyperchromatic and pleomorphic, the so-called 'endocrine atypia' (36).

The oxyphilic (or oncocytic) adenomas consist mainly of oxyphilic cells and are usually non-functional. They are usually soft, ellipsoid or lobulated with variable brownish colors. Microscopically, oxyphilic adenomas are composed of sheets, anastomosing cords and acinar arrangement of polygonal cells with abundant granular, brightly eosinophilic cytoplasm and centrally placed rounded nuclei (35).

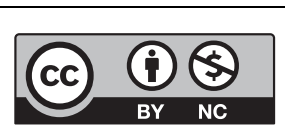

This work is licensed under a Creative Commons Attribution-NonCommercial 4.0 International License. 
The large clear cell (light chief cell) adenoma is another rare variant of adenoma, and they are comprised of polygonal cells with cytoplasmic vacuoles filled with glycogen. They exhibit positivity in Periodic Acid-Schiff (PAS) staining, with or without diastase digestion. The water-clear cell adenoma consists of nests and acini with clear cells containing abundant foamy, granular cytoplasm and mild nuclear pleomorphism. They are thought to be large clear cell adenomas with glycogen accumulation rather than true water-clear cells with membrane bound vesicles. Lipoadenomas have also been described and are characterized by nests and cords of chief cells with a few oxyphil cells intimately admixed with variable amount of mature adipose tissue and fibrous stroma (34). They may be non-functional or rarely may present with primary hyperparathyroidism (35).

It should also be mentioned that there are tumors with some features suggesting malignancy, but falling short of unequivocal histological diagnosis of malignancy, which are termed 'atypical adenoma'. The usual histopathological features include fibrous bands, pronounced trabecular growth, remarkable mitotic activity ( $>1$ mitosis per 10 high-power fields), tumor necrosis and incomplete invasion of the capsule. The significance of the remarkable mitotic activity is unclear. Their detection should prompt careful assessment, while searching for other features of malignancy (34).

\section{Primary hyperplasia: multiple gland disease}

Parathyroid hyperplasia usually affects $10-15 \%$ of sporadic cases with pHPT. It involves may be diffuse or asymmetrical and involve some glands $(34,37)$. Asynchronous presentation may also occur (34). The glands are enlarged, hypercellular and functioning with decreased or absent intracellular fat, as indicated by fat staining (38). The glands may demonstrate diffuse proliferation of parenchymal cells, with little or no extracellular fat or nodular development consisting mainly by chief cells, although foci of oncocytes and clear cells may be admixed (37).

There are two major types of histological hyperplastic proliferation patterns. One is the chief cell hyperplasia pattern and the other is the clear cell hyperplasia pattern. The above variation implies that there are different molecular pathways that lead to the development of hyperplastic multiple gland disease. Primary chief cell hyperplasia may be observed predominantly in sporadic and also in hereditary forms of pHPT.
Hyperplasia occurs predominantly in chief cells in this histological subtype. Gland enlargement can by either symmetrical or asymmetrical occurring only in some glands. Of interest is the fact that although within a single gland the growth pattern is usually diffuse, in some cases, it presents with a nodular intraglandular pattern of growth with foci of normal parathyroid tissue. The latter is seen in hereditary disease, usually multiple endocrine neoplasia type 1, suggesting formation of multiple adenomas involving all glands rather than true diffuse hyperplasia in these patients.

Water cell hyperplasia is rare and is never associated to hereditary disease. In this entity all glands are diffusely pathologic (36).

\section{Parathyroid carcinoma}

Parathyroid carcinoma is a rare lesion whose histological diagnosis could be challenging. It may require the presence of distant metastasis in order to confirm the diagnosis. Histological findings could include those seen in atypical adenomas with some additional evidence of invasion. Abnormal mitotic activity appears to be a feature, but not pathognomonic of this entity. The World Health Organization suggests that the following criteria must be fulfilled in order to confirm the diagnosis: presence of vascular invasion (in the capsule or adjacent tissues), capsular invasion with extension to adjacent tissues and/or presence of metastases.

Recently, De Lellis mentioned that most carcinomas have a solid growth pattern with tumor cells arranged in diffuse masses, small nests or trabeculae, some tumors exhibiting spindle cell, follicular or papillary patterns $(39,40)$. There is no variation in nuclear size and shape, and this may be an indistinguishable feature from adenomas. Some tumors exhibit pleomorphism with coarse chromatin and macronucleoli, a feature that must be distinguished from the so-called endocrine atypia encountered in parathyroid adenomas and other benign endocrine tumors (39).

\section{Molecular pathways and genetic involvement in sporadic PHPT}

Tumorigenesis may involve multiple different mechanisms responsible for hyperplastic changes such as activation of oncogenes, inactivation of tumor suppressor genes, imbalance between growth factors and proteins involved in cell regulation and epigenetic alterations

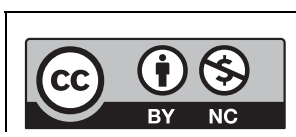

This work is licensed under a Creative Commons Attribution-NonCommercial 4.0 International License. 
$(41,42)$. Genes involved in these processes that have been associated with sporadic pHPT are analyzed below.

\section{Pathways and genes involving cell cycle regulators}

The cell cycle is a series of events that take place in the cell and lead to its division. Cyclins are proteins that are involved in the regulation of progression of cells through the cell cycle and activate cyclin-dependent kinases (CDKs) (43). The expression of cyclin genes regulates the activity of CDKs (43). Elevated levels of cyclin D1 (CCND1, PRAD1) have been shown to promote cell cycle progression. CCND1 gene has been found to be overexpressed in sporadic parathyroid adenomas and carcinomas $(43,44,45)$. On the other hand, CDK inhibitors also regulate cellular proliferation and apoptosis, by inhibiting the complex cyclin-CDK (43). CDK inhibitor 1B (P27, CDKN1B) and CDK inhibitor 1A (P21) are members of the CDK inhibitor proteins. Studies have shown that sporadic parathyroid carcinomas have decreased P27 and P21 expression (43), while low-frequency germline and somatic mutations have also been reported in patients with adenomas $(46,47,48)$. CCND1 gene has been found to be overexpressed in sporadic parathyroid adenomas and carcinomas $(43,44,45)$ (Fig. 1).
Another inhibitor of cell cycle progression is retinoblastoma protein (RB). It works as a tumor suppressor factor. Allelic loss of the $R B$ gene was found to be involved in parathyroid carcinomas (25). Proliferating cellular nuclear antigen (PCNA) has been studied and shown to interact with other proteins involved in DNA replication and repair, cell cycle control, chromatin remodeling/epigenetic inheritance, chromatid cohesion and transcription (49). PCNA acts as a cofactor for DNA polymerase $\mathrm{D}$ and interacts with CYCLIN D1 $(49,50)$. It was recently demonstrated that PCNA was considerably higher in adenomas, followed by primary hyperplasias, whereas PCNA in common adenoma and other hyperplastic changes were even lower than those in healthy parathyroid glands $(51,52)$.

Recent studies showed that about $40-45 \%$ of sporadic parathyroid tumors show MEN1 gene mutations. Sporadic parathyroid tumors harboring MEN1 gene somatic mutations frequently evidence $\mathrm{LOH}$ on chromosome region 11q13 $(53,54,55)$. Targeted inactivation of MEN1 gene specifically to the parathyroid glands resulted in parathyroid neoplasia accompanied by hypercalcemic hyperparathyroidism (56). Loss of heterozygosity of chromosome 11q, the genomic location of the MEN1 gene, is the most frequent genomic aberration found

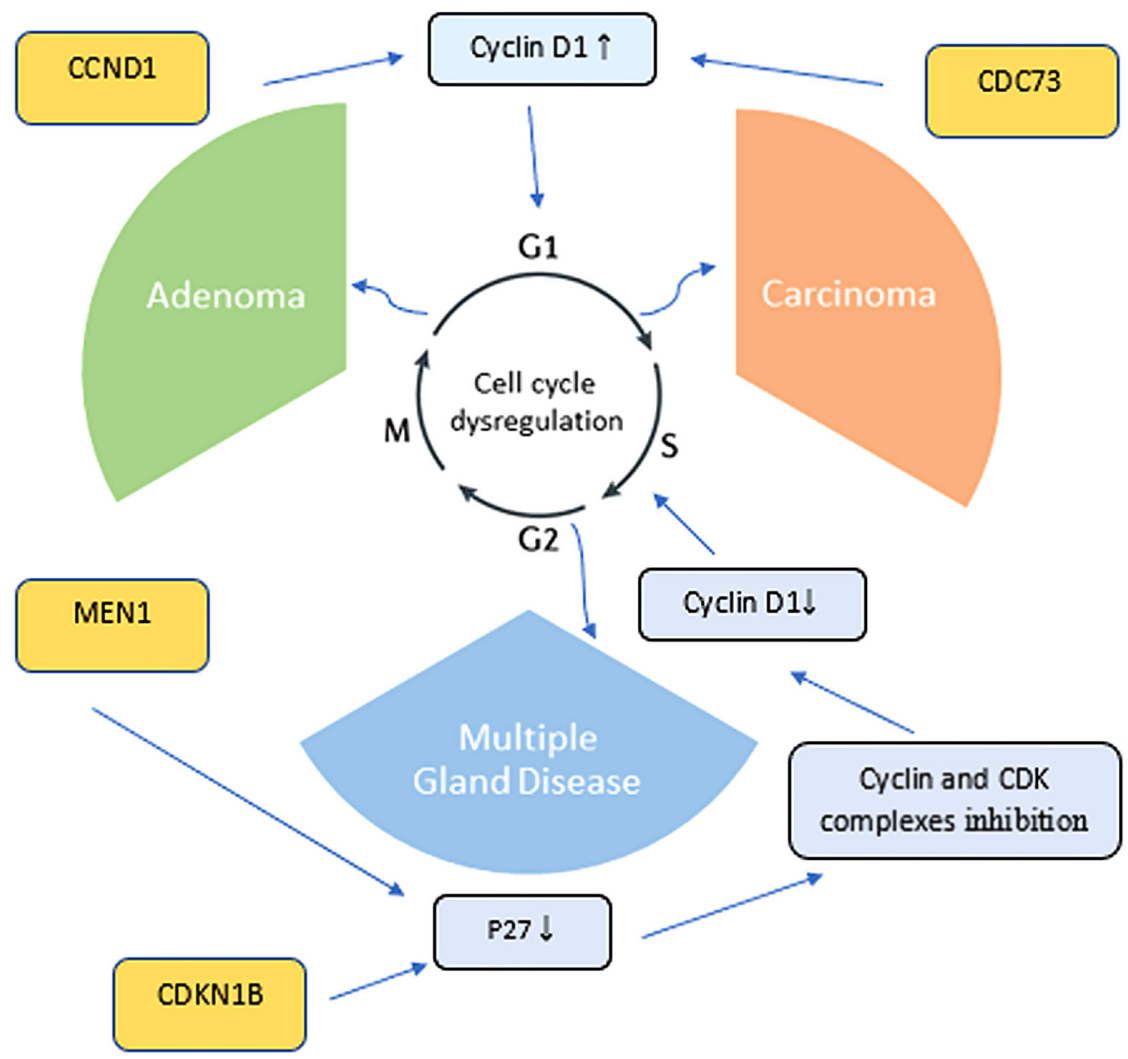

Figure 1

Parathyroid tumorigenesis mechanisms via the cyclins pathway. CCND1 gene, encoding cyclin D1, is upregulated in parathyroid adenomas. MEN1 gene inactivation results in a reduction of $\mathrm{P} 27$ and inhibition of cyclin and CDK complexes, as well as a loss of control of cell cycle progression. Inactivating somatic and germline mutations of $C D C 73$ are frequently identified in patients with parathyroid carcinoma. $C D K N 1 B$ has been reported to be downregulated in adenomas compared to normal tissues. http://www.endocrineconnections.org https://doi.org/10.1530/EC-17-0283 (c) 2018 The authors Published by Bioscientifica Ltd

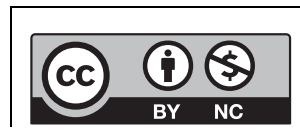

This work is licensed under a Creative Commons Attribution-NonCommercial 4.0 International License. 
in parathyroid adenomas (56). The product of MEN1 gene, called menin, can function as suppressor of transcription, because this protein is able to bind a family of transcription factors such as AP-1/Jun-Fos family, and it is also associated with a histone methyltransferase (HMT) complex leading to an increased expression of cyclindependent kinase inhibitors (CDKIs) and consequently suppressing cell growth $(57,58)$.

Latest data on sporadic pHPT have concluded on specific genes being upregulated or downregulated, mostly on sporadic adenomas (4). Non-familial pHPT patients (almost 90\% of patients with pHPT) may carry somatic mutations in specific genes like MEN1, CCND1, RB, RIZ1, CTNN3 and LRP5 genes (4). However, sporadic forms of pHPT may also be associated with germline mutations involving MEN1, CDC73, CASR, CDKI or PTH genes (4). It is estimated that $10 \%$ of patients presenting with sporadic pHPT under the age of 45 years, carry a de novo germline mutation in MEN1, CDC73 or CASR genes $(4,59,60)$. In addition, almost $5 \%$ of patients with pHPT presenting in the sixth to ninth decades of life with a single adenoma and without family history of parathyroid disease, MEN or other endocrine tumor syndromes, may carry germline mutations of the CDKI genes (usually involving CDKN1A (P21), CDKN2B (P15) or CDKN2C (P18)) $(4,61)$. A PTH nonsense mutation, Arg83Stop, has also been associated with hypercalcemia due to parathyroid adenoma and an undetectable PTH (62).

\section{Wnt/ $\beta$-catenin signaling pathway and genetic alterations causing its dysfunction in pHPT}

Another important pathway that should be mentioned is the Wnt/ $\beta$-catenin signaling pathway, which affects multiple cellular functions mainly through gene transcription. Dysregulation of this pathway with subsequent accumulation of $\beta$-catenin in the cell cytoplasm or nucleus has been implicated in carcinogenesis (48). When cells bind a Wnt-ligand, the protein binds to frizzled receptors, LRP5/6 co-receptors and a destruction complex (for example, APC, AXIN, GSK-3B, DVL). This binding causes Axin dephosphorylation and degradation and the production of the non-phosphorylated and active $\beta$-catenin. The latter binds to the LEF/TCF family of transcription factors and regulates gene transcription (48). Mutant proteins of the Wnt pathway have been associated with some forms of cancer. Stabilizing $\beta$-catenin mutations and resistance to cytoplasmic dephosphorylation and degradation, causes accumulation of non-phosphorylated active $\beta$-catenin and have been associated with parathyroid

$$
\text { http://www.endocrineconnections.org }
$$

tumorigenesis and pHPT $(48,63)$. In addition, the absence of stabilizing mutations of beta-catenin encoded by CTNNB1 exon 3 has been reported in a large series of sporadic parathyroid adenomas (64).

Two low frequency $\beta$-catenin stabilizing mutations have been identified and reported in parathyroid adenomas (Ser37Ala $(48,63)$ and Ser33Cys $(63,65,66))$, but more studies are required to substantiate this genetic disorder. In parathyroid adenomas without a stabilizing $\beta$-catenin mutation, the accumulation of the protein may also be due to an aberrantly spliced internally truncated Wnt receptor LRP5 (LRP5 $\Delta$ ). This disabled receptor was found to be expressed in $86 \%$ of the investigated parathyroid adenomas causing pHPT (67). In some investigated parathyroid adenomas, the MYC oncogene was found to be overexpressed and regulated by $\beta$-catenin activity in a human parathyroid cell line, as was expression of the CCND1 oncogene $(68,69)$.

\section{Pathways involving growth factors and reported genetic predisposition to pHPT}

Growth factors can affect cellular growth, proliferation, tissue repairing and homeostasis and any imbalance could lead to tumorigenesis (43). Angiogenesis is a key process for the emergence and survival of proliferative lesions, as it involves the formation of new vessels from existing ones to ensure that oxygen and other necessary nutrients will be transferred to the tumor. Factors that are found to be overexpressed in pHPT include vascular endothelial growth factor (VEGF), fibroblast growth factor (FGF), transforming growth factor beta (TGF $\beta$ ) and insulin growth factor-1 (IGF-1) (43). Genes affecting growth factor expression are found to be involved in sporadic $\mathrm{pHPT}$.

VEGF is regulating angiogenesis in normal or pathological states. It is implicated in tumorigenesis and in parathyroid proliferating lesions, it has a proangiogenic effect (43). Basic FGF (FGF-2) is also found to be upregulated in parathyroid tumors (70). FGF-2 is involved both in cell cycle regulation as well as in angiogenesis, tissue growth and repair $(43,71)$. FGF-2 and VEGF act synergistically on angiogenesis in cultured epithelial cells $(71,72)$. TGF $\beta$ is found to affect multiple cellular processes, including angiogenesis, and it is increased in patients with pHPT (73). In low dosage, it acts in favor of cell proliferation, while in high dosage, it inhibits proliferation (43). IGF-1 is the effector for the action of growth hormone. It is also a mediator of parathormone anabolic effects on bones. It is found to stimulate cellular proliferation, and it is implicated in the growth regulation of parathyroid tumors (74).

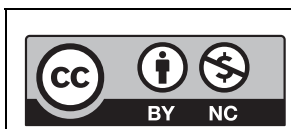

This work is licensed under a Creative Commons Attribution-NonCommercial 4.0 International License. 


\section{Apoptotic pathways and genetic factors involved in PHPT}

Apoptosis is a form of programmed cell death, which ensures the tissue homeostasis and the maintenance of certain number of cells (75). Mechanisms involved in the pathogenesis of pHPT also include an imbalance between apoptotic and anti-apoptotic factors, some of which are tumor necrosis factor (TNF)-related apoptosis-inducing ligand (TRAIL), Fas receptor, the BCL family, the mouse double minute 2 homolog (MDM2) and tumor protein 53 (P53) $(43,75)$.

TRAIL is a protein that induces caspase 8-dependent apoptosis, via death receptors DR4 and DR5 (75). It has been implicated in anticancer activity and cardiovascular disease prevention, lipid uptake and blood vessel homeostasis $(75,76,77,78,79)$. However, TRAIL can have an opposite role in apoptosis when forming complexes with transmitters such as Fas-associated with a death domain (FADD) or caspase- $8(80,81)$. TRAIL gene has been found to be overexpressed in parathyroid adenomas and hyperplasias compared to normal tissue (43).

FAS receptor is a death receptor causing apoptosis by forming the death-inducing signaling complex (DISC) (75). Parathyroid adenomas and hyperplasias demonstrated overexpression of the FAS gene compared to normal tissue. Hyperplasias showed the highest expression, whereas in adenomas, the expression of the FAS gene was increased compared to normal tissue, but it was lower than that in hyperplasias (41).

The BCL-2 is a family of proteins that regulates caspase activation and mitochondrial outer membrane permeabilization (43). The anti-apoptotic BCL-X(L) and BCL-W genes were higher in adenomas compared to hyperplasias (43). The expression of pro-apoptotic members of the BCL-2 family, like BIM and BOK, was decreased in both adenomas and hyperplasias (43). Mutations in the $B I M$ gene may lead to resistance to apoptosis (43). MDM2 is a negative regulator of the tumor suppressor P53, acts as an oncogene, and it is found to be overexpressed in multiple tumor types like sarcomas and breast cancer (43). It seems that BCL-2 and MDM2 have no expression in parathyroid carcinoma, while they are expressed in adenomas and hyperplasias $(41,43)$. In addition, P53 was found to be overexpressed in parathyroid carcinomas, Fas and p53 expression is correlated in hyperplasia, while there is no relation between FAS, Ki-67 and PCNA $(43,82)$.

There are a few recent studies trying to set the genetic background of primary parathyroid hyperplasia vs adenoma via the differential gene expression profile

http://www.endocrineconnections.org https://doi.org/10.1530/EC-17-0283

2018 The authors Published by Bioscientifica Ltd
Table 2 Genes reported to be involved in sporadic PHPT.

\begin{tabular}{|c|c|c|c|c|}
\hline & Genes & Adenoma & $\begin{array}{c}\text { Multiple } \\
\text { gland } \\
\text { disease }\end{array}$ & Carcinoma \\
\hline \multirow{14}{*}{$\begin{array}{l}\text { Cell cycle } \\
\text { regulator genes }\end{array}$} & CCND1 & $\checkmark$ & & $\checkmark$ \\
\hline & $P 27$ & $\checkmark$ & & $\checkmark$ \\
\hline & $P 21$ & $\checkmark$ & & $\checkmark$ \\
\hline & P18 & $\checkmark$ & & \\
\hline & P15 & $\checkmark$ & & \\
\hline & PCNA & $\checkmark$ & $\checkmark$ & \\
\hline & $R B$ & & & $\checkmark$ \\
\hline & MEN1 & $\checkmark$ & & \\
\hline & $R I Z 1$ & $\checkmark$ & & \\
\hline & CTNN3 & $\checkmark$ & & \\
\hline & $L R P 5$ & $\checkmark$ & & \\
\hline & $C D C 73$ & $\checkmark$ & & $\checkmark$ \\
\hline & CASR & $\checkmark$ & & \\
\hline & PTH & $\checkmark$ & & \\
\hline \multirow{4}{*}{$\begin{array}{l}\text { Wnt/ } \beta \text {-catenin } \\
\text { pathway }\end{array}$} & CTNNB1 & $\checkmark$ & & \\
\hline & $L R P 5 \triangle$ & $\checkmark$ & & \\
\hline & $M Y C$ & $\checkmark$ & & \\
\hline & CCND1 & $\checkmark$ & & \\
\hline \multirow[t]{11}{*}{ Apoptotic factors } & TRAIL & $\checkmark$ & $\checkmark$ & $\checkmark$ \\
\hline & FAS & $\checkmark$ & $\checkmark$ & $\checkmark$ \\
\hline & $B C L-X(L)$ & $\checkmark$ & & \\
\hline & $B C L-W$ & $\checkmark$ & & \\
\hline & $B C L-2$ & $\checkmark$ & $\checkmark$ & \\
\hline & MDM2 & $\checkmark$ & $\checkmark$ & \\
\hline & P53 & & $\checkmark$ & $\checkmark$ \\
\hline & $T B X A 2 R$ & & $\checkmark$ & \\
\hline & FHIT & & $\checkmark$ & \\
\hline & PTGDS & & $\checkmark$ & \\
\hline & $E G F R$ & & $\checkmark$ & \\
\hline \multirow[t]{4}{*}{ Growth factors } & $V E G F$ & $\checkmark$ & $\checkmark$ & $\checkmark$ \\
\hline & $F G F$ & $\checkmark$ & $\checkmark$ & $\checkmark$ \\
\hline & $T G F B$ & $\checkmark$ & $\checkmark$ & $\checkmark$ \\
\hline & $I G F-1$ & $\checkmark$ & $\checkmark$ & $\checkmark$ \\
\hline
\end{tabular}

$(83,84,85,86)$. Data from one study revealed more than 200 genes being differentially expressed among hyperplasia and adenoma (85). The most statistically significant ones being upregulated were the HOOK 1 protein, the thromboxane $\mathrm{A} 2$ receptor gene (TBXA2R) and the fragile histidine triad gene (FHIT) (85). The downregulated genes were the prostaglandin-d synthase gene (PTGDS) and EGFR (downregulated in hyperplasia) (85). All referred genes are listed in Table 2.

\section{miRNA differential expression and parathyroid tumorigenesis}

MicroRNAs (miRNA) are small non-coding, singlestranded RNAs, 19-25 nucleotides long, which exert regulatory functions such as regulation of gene expression through multiple mechanisms including decreased 
translation, increased degradation of the target messenger RNA (mRNA) or both (8). Binding of miRNA to its target mRNA results in the repression of translation (8). miRNA genes may act as oncogenes or tumor suppressor genes (87). Differentially expressed miRNAs have been reported in parathyroid adenomas and carcinomas, compared to normal parathyroid tissue (88). Recent data suggest a specific expression pattern of miRNAs in parathyroid carcinoma $(2,89)$. Among the downregulated miRNAs, miR-296, miR-139, miR-126-5p, miR-26b and miR-30b are differentially expressed in parathyroid carcinomas $(2,82)$. However, there are limited data on miRNA expression profile in the so-called sporadic primary hyperplasia (2), compared to parathyroid adenoma or carcinoma. Rahbari and coworkers suggested the existence of 22 uniquely expressed miRNA in parathyroid hyperplasia, which need to be validated in other cohorts as well (2).

\section{Summary-clinical implications}

Sporadic pHPT is a common clinical entity with many of its aspects needed to be elucidated. It would be of great interest to investigate further the genetic deregulation of parathyroid tumors, as it may provide new aspects in the earlier and accurate pre-operational diagnosis and management. The clarification of the molecular pathways affecting parathyroid tumorigenesis will elucidate the pathogenetic mechanisms and will probably suggest new therapeutic approaches, targeting in the repression of deregulation of the affected pathways.

\section{Declaration of interest}

The authors declare that there is no conflict of interest that could be perceived as prejudicing the impartiality of this review.

\section{Funding}

This study was conducted as part of a PhD project and funded by the Hellenic Endocrine Society.

\section{References}

1 Kebebew E \& Clark O. Parathyroid adenoma, hyperplasia, and carcinoma: localization, technical details of primary neck exploration, and treatment of hypercalcemic crisis. Surgical Oncology Clinics of North America 19987721.

2 Rahbari R, Holloway AK, He M, Khanafshar E, Clark OH \& Kebebew E. Identification of differentially expressed microRNA in parathyroid tumors. Annals of Surgical Oncology 201118 1158-1165. (https://doi.org/10.1245/s10434-010-1359-7)

http://www.endocrineconnections.org https://doi.org/10.1530/EC-17-0283
(C) 2018 The authors Published by Bioscientifica Ltd
3 Adami S, Marcocci C \& Gatti D. Epidemiology of primary hyperparathyroidism in Europe. Journal of Bone and Mineral Research 200217 N18-N23.

4 Thakker R. Genetics of parathyroid tumours. Journal of Internal Medicine 2016280 574-583. (https://doi.org/10.1111/joim.12523)

5 Mallya SM \& Arnold A. Cyclin D1 in parathyroid disease. Frontiers in Bioscience 20005 d367-d371. (https://doi.org/10.2741/Mallya)

6 Calender A \& Cougard P. Primary hyperparathyroidism: genetic heterogeneity suggesting different pathogenesis in sporadic and familial forms of parathyroid hyperplasia and tumors. European Journal of Endocrinology $1996 \mathbf{1 3 4}$ 263-266. (https://doi.org/10.1530/ eje.0.1340263)

7 Costa-Guda J \& Arnold A. Genetic and epigenetic changes in sporadic endocrine tumors: parathyroid tumors. Molecular and Cellular Endocrinology 2014386 46-54. (https://doi.org/10.1016/j. mce.2013.09.005)

8 Verdelli C, Forno I, Vaira V \& Corbetta S. Epigenetic alterations in human parathyroid tumors. Endocrine 201549 324-332. (https://doi. org/10.1007/s12020-015-0555-4)

9 Pallan S, Rahman MO \& Khan AA. Diagnosis and management of primary hyperparathyroidism. BMJ 2012344 e1013. (https://doi. org/10.1136/bmj.e1013)

10 Wilhelm SM, Wang TS, Ruan DT, Lee JA, Asa SL, Duh Q-Y, Doherty GM, Herrera MF, Pasieka JL \& Perrier ND. The American association of endocrine surgeons guidelines for definitive management of primary hyperparathyroidism. JAMA Surgery 2016 151 959-968. (https://doi.org/10.1001/jamasurg.2016.2310)

11 Khan A, Hanley D, Rizzoli R, Bollerslev J, Young J, Rejnmark L, Thakker R, D’Amour P, Paul T \& Van Uum S. Primary hyperparathyroidism: review and recommendations on evaluation, diagnosis, and management. A Canadian and International Consensus. Osteoporosis International 201728 1-19. (https://doi. org/10.1007/s00198-016-3716-2)

12 Vargas-Poussou R, Mansour-Hendili L, Baron S, Bertocchio J-P, Travers C, Simian C, Treard C, Baudouin V, Beltran S \& Broux F. Familial hypocalciuric hypercalcemia types 1 and 3 and primary hyperparathyroidism: similarities and differences. Journal of Clinical Endocrinology and Metabolism 2016101 2185-2195. (https://doi. org/10.1210/jc.2015-3442)

13 Bilezikian JP, Brandi ML, Eastell R, Silverberg SJ, Udelsman R, Marcocci C \& Potts JT Jr. Guidelines for the management of asymptomatic primary hyperparathyroidism: summary statement from the Fourth International Workshop. Journal of Clinical Endocrinology and Metabolism 201499 3561-3569. (https://doi. org/10.1210/jc.2014-1413)

14 Maruani Gr, Hertig A, Paillard M \& Houillier P. Normocalcemic primary hyperparathyroidism: evidence for a generalized target-tissue resistance to parathyroid hormone. Journal of Clinical Endocrinology and Metabolism 200388 4641-4648. (https://doi.org/10.1210/ jc.2002-021404)

15 Titon I, Cailleux-Bounacer A, Basuyau JP, Lefebvre H, Savouré A \& Kuhn JM. Evaluation of a standardized short-time calcium suppression test in healthy subjects: interest for the diagnosis of primary hyperparathyroidism. European Journal of Endocrinology 2007 157 351-357. (https://doi.org/10.1530/EJE-07-0132)

16 Bilezikian JP \& Silverberg SJ. Normocalcemic primary hyperparathyroidism. Arquivos Brasileiros de Endocrinologia e Metabologia 201054 106-109. (https://doi.org/10.1590/S000427302010000200004)

17 Hagag P, Revet-Zak I, Hod N, Horne T, Rapoport M \& Weiss M. Diagnosis of normocalcemic hyperparathyroidism by oral calcium loading test. Journal of Endocrinological Investigation 200326 327-332. (https://doi.org/10.1007/BF03345180)

18 Monchik J, Lamberton R \& Roth U. Role of the oral calciumloading test with measurement of intact parathyroid hormone in 
the diagnosis of symptomatic subtle primary hyperparathyroidism. Surgery 1992112 1103-1110.

19 Monchik JM. Presidential address: normocalcemic hyperparathyroidism. Surgery 1995118 917-923. (https://doi. org/10.1016/S0039-6060(05)80094-7)

20 Zhu X, Shan C, Zhu Q, Song L, Zhou Y, Liu J \& Zhang K. Clinical value of calcium load test in differential diagnosis of different types of hyperparathyroidism. International Journal of Clinical and Experimental Medicine 201475445.

21 Forman D \& Lorenzo L. Ionized calcium: its significance and clinical usefulness. Annals of Clinical and Laboratory Science 199121 297-304.

22 Christensen SE, Nissen PH, Vestergaard P, Heickendorff L, Brixen K $\&$ Mosekilde L. Discriminative power of three indices of renal calcium excretion for the distinction between familial hypocalciuric hypercalcaemia and primary hyperparathyroidism: a follow-up study on methods. Clinical Endocrinology 200869 713-720. (https://doi. org/10.1111/j.1365-2265.2008.03259.x)

23 Silverberg SJ, Clarke BL, Peacock M, Bandeira F, Boutroy S, Cusano NE, Dempster D, Lewiecki EM, Liu J-M \& Minisola S. Current issues in the presentation of asymptomatic primary hyperparathyroidism: proceedings of the Fourth International Workshop. Journal of Clinical Endocrinology and Metabolism 201499 3580-3594. (https://doi.org/10.1210/jc.2014-1415)

24 Kunstman JW, Kirsch JD, Mahajan A \& Udelsman R. Parathyroid localization and implications for clinical management. Journal of Clinical Endocrinology and Metabolism 201398 902-912. (https://doi. org/10.1210/jc.2012-3168)

25 Frøkjaer VG \& Mollerup CL. Primary hyperparathyroidism: renal calcium excretion in patients with and without renal stone disease before and after parathyroidectomy. World Journal of Surgery 200226 532-535.

26 Khosla S, Melton LJ, Wermers RA, Crowson CS, O'fallon WM \& Riggs BL. Primary hyperparathyroidism and the risk of fracture: a population-based study. Journal of Bone and Mineral Research 199914 1700-1707. (https://doi.org/10.1359/jbmr.1999.14.10.1700)

27 Mollerup CL, Vestergaard P, Frøkjær VG, Mosekilde L, Christiansen P $\&$ Blichert-Toft M. Risk of renal stone events in primary hyperparathyroidism before and after parathyroid surgery: controlled retrospective follow up study. BMJ 2002325 807. (https://doi. $\operatorname{org} / 10.1136 / \mathrm{bmj} .325 .7368 .807)$

28 Vestergaard P, Mollerup CL, Frøkjær VG, Christiansen P, BlichertToft M \& Mosekilde L. Cohort study of risk of fracture before and after surgery for primary hyperparathyroidism. BMJ $2000 \mathbf{3 2 1}$ 598-602. (https://doi.org/10.1136/bmj.321.7261.598)

29 Udelsman R, Åkerström G, Biagini C, Duh Q-Y, Miccoli P, Niederle B $\&$ Tonelli F. The surgical management of asymptomatic primary hyperparathyroidism: proceedings of the Fourth International Workshop. Journal of Clinical Endocrinology and Metabolism 201499 3595-3606. (https://doi.org/10.1210/jc.2014-2000)

30 Chang Y-J, Mittal V, Remine S, Manyam H, Sabir M, Richardson T \& Young S. Correlation between clinical and histological findings in parathyroid tumors suspicious for carcinoma. American Surgeon 2006 72 419-426.

31 Agarwal G, Nanda G, Kapoor A, Singh KR, Chand G, Mishra A, Agarwal A, Verma AK, Mishra SK \& Syal SK. Cardiovascular dysfunction in symptomatic primary hyperparathyroidism and its reversal after curative parathyroidectomy: results of a prospective case control study. Surgery 2013154 1394-1404. (https://doi. org/10.1016/j.surg.2013.06.047)

32 Peacock M, Bolognese MA, Borofsky M, Scumpia S, Sterling LR, Cheng S \& Shoback D. Cinacalcet treatment of primary hyperparathyroidism: biochemical and bone densitometric outcomes in a five-year study. Journal of Clinical Endocrinology and Metabolism 200994 4860-4867. (https://doi.org/10.1210/jc.20091472)
33 Rothe H, Liangos O, Biggar P, Petermann A \& Ketteler M. Cinacalcet treatment of primary hyperparathyroidism. International Journal of Endocrinology 201120115.

34 van der Walt J. Pathology of the parathyroid glands. Diagnostic Histopathology 201218 221-233. (https://doi.org/10.1016/j. mpdhp.2012.03.006)

35 Shakeel S \& Mubarak M. Proliferative lesions of parathyroid glands: an update for practicing pathologists. Journal of the College of Physicians and Surgeons: Pakistan 201626 51-59.

36 DeLellis RA. Parathyroid tumors and related disorders. Modern Pathology 201124 S78-S93. (https://doi.org/10.1038/ modpathol.2010.132)

37 Baloch ZW \& LiVolsi VA. Pathology of the parathyroid glands in hyperparathyroidism. Seminars in Diagnostic Pathology 201330 165-177. (https://doi.org/10.1053/j.semdp.2013.06.003)

38 Sadow PM. Endocrine Pathology, An Issue of Surgical Pathology Clinics, vol 7-4. London, UK: Elsevier Health Sciences, 2014.

39 DeLellis RA. Challenging lesions in the differential diagnosis of endocrine tumors: parathryoid carcinoma. Endocrine Pathology 2008 19 221-225. (https://doi.org/10.1007/s12022-008-9050-2)

40 DeLellis RA. Pathology and Genetics of Tumours of Endocrine Organs, 3rd edn, vol 8. Lyon, France: IARC Press, 2004.

41 Árvai K, Nagy K, Barti-Juhász H, Peták I, Krenács T, Micsik T, Végső G, Perner F \& Szende B. Molecular profiling of parathyroid hyperplasia, adenoma and carcinoma. Pathology and Oncology Research 201218 $607-614$

42 Imanishi Y. Molecular pathogenesis of tumorigenesis in sporadic parathyroid adenomas. Journal of Bone and Mineral Metabolism 2002 20 190-195. (https://doi.org/10.1007/s007740200027)

43 Segiet OA, Deska M, Michalski M, Gawrychowski J \& Wojnicz R. Molecular profiling in primary hyperparathyroidism. Head and Neck 201537 299-307. (https://doi.org/10.1002/hed.23656)

44 Hemmer S, Wasenius V-M, Haglund C, Zhu Y, Knuutila S, Franssila K \& Joensuu H. Deletion of 11q23 and cyclin D1 overexpression are frequent aberrations in parathyroid adenomas. American Journal of Pathology 2001158 1355-1362. (https://doi.org/10.1016/S00029440(10)64086-2)

45 Hsi ED, Zukerberg LR, Yang WI \& Arnold A. Cyclin D1/PRAD1 expression in parathyroid adenomas: an immunohistochemical study. Journal of Clinical Endocrinology and Metabolism $1996 \mathbf{8 1}$ 1736-1739.

46 Buchwald PC, Åkerström G \& Westin G. Reduced p18INK4c, p21CIP1/WAF1 and p27KIP1 mRNA levels in tumours of primary and secondary hyperparathyroidism. Clinical Endocrinology 200460 389-393. (https://doi.org/10.1111/j.1365-2265.2004.01995.x)

47 Costa-Guda J, Marinoni I, Molatore S, Pellegata NS \& Arnold A. Somatic mutation and germline sequence abnormalities in CDKN1B, encoding p27Kip1, in sporadic parathyroid adenomas. Journal of Clinical Endocrinology and Metabolism 201196 E701-E706. (https://doi.org/10.1210/jc.2010-1338)

48 Westin G. Molecular genetics and epigenetics of nonfamilial (sporadic) parathyroid tumours. Journal of Internal Medicine 2016280 551-558. (https://doi.org/10.1111/joim.12458)

49 Shivji MK, Kenny MK \& Wood RD. Proliferating cell nuclear antigen is required for DNA excision repair. Cell 199269 367-374. (https://doi.org/10.1016/0092-8674(92)90416-A)

50 Xiong Y, Zhang H \& Beach D. D type cyclins associate with multiple protein kinases and the DNA replication and repair factor PCNA. Cell 199271 505-514. (https://doi.org/10.1016/0092-8674(92)90518-H)

51 Loda M, Lipman J, Cukor B, Bur M, Kwan P \& DeLellis RA. Nodular foci in parathyroid adenomas and hyperplasias: an immunohistochemical analysis of proliferative activity. Human Pathology 199425 1050-1056. (https://doi.org/10.1016/0046-8177(94)90064-7)

52 Yamaguchi S, Yachiku S \& Morikawa M. Analysis of proliferative activity of the parathyroid glands using proliferating cell nuclear

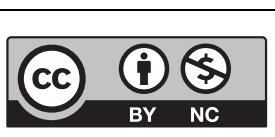

This work is licensed under a Creative Commons Attribution-NonCommercial 4.0 International License. 
antigen in patients with hyperparathyroidism 1. Journal of Clinical Endocrinology and Metabolism 199782 2681-2688.

53 Cromer MK, Starker LF, Choi M, Udelsman R, Nelson-Williams C, Lifton RP \& Carling T. Identification of somatic mutations in parathyroid tumors using whole-exome sequencing. Journal of Clinical Endocrinology and Metabolism 201297 E1774-E1781. (https://doi.org/10.1210/jc.2012-1743)

54 Lemos MC \& Thakker RV. Multiple endocrine neoplasia type 1 (MEN1): analysis of 1336 mutations reported in the first decade following identification of the gene. Human Mutation 200829 22-32. (https://doi.org/10.1002/humu.20605)

55 Newey PJ, Nesbit MA, Rimmer AJ, Attar M, Head RT, Christie PT, Gorvin CM, Stechman M, Gregory L \& Mihai R. Whole-exome sequencing studies of nonhereditary (sporadic) parathyroid adenomas. Journal of Clinical Endocrinology and Metabolism 201297 E1995-E2005. (https://doi.org/10.1210/jc.2012-2303)

56 Libutti SK, Crabtree JS, Lorang D, Burns AL, Mazzanti C, Hewitt SM, O'Connor S, Ward JM, Emmert-Buck MR \& Remaley A. Parathyroid gland-specific deletion of the mouse Men1 gene results in parathyroid neoplasia and hypercalcemic hyperparathyroidism. Cancer Research $2003638022-8028$.

57 Agarwal SK, Guru SC, Heppner C, Erdos MR, Collins RM, Park SY, Saggar S, Chandrasekharappa SC, Collins FS \& Spiegel AM. Menin interacts with the AP1 transcription factor JunD and represses JunD-activated transcription. Cell 199996 143-152. (https://doi. org/10.1016/S0092-8674(00)80967-8)

58 Milne TA, Hughes CM, Lloyd R, Yang Z, Rozenblatt-Rosen O, Dou Y, Schnepp RW, Krankel C, LiVolsi VA \& Gibbs D. Menin and MLL cooperatively regulate expression of cyclin-dependent kinase inhibitors. PNAS 2005102 749-754. (https://doi.org/10.1073/ pnas.0408836102)

59 Hannan FM, Nesbit MA, Christie PT, Lissens W, Van der Schueren B, Bex M, Bouillon R \& Thakker RV. A homozygous inactivating calcium-sensing receptor mutation, Pro339Thr, is associated with isolated primary hyperparathyroidism: correlation between location of mutations and severity of hypercalcaemia. Clinical Endocrinology 201073 715-722. (https://doi.org/10.1111/j.13652265.2010.03870.x)

60 Starker LF, Åkerström T, Long WD, Delgado-Verdugo A, Donovan P, Udelsman R, Lifton RP \& Carling T. Frequent germ-line mutations of the MEN1, CASR, and HRPT2/CDC73 genes in young patients with clinically non-familial primary hyperparathyroidism. Hormones and Cancer 20123 44-51. (https://doi.org/10.1007/ s12672-011-0100-8)

61 Costa-Guda J, Soong C-P, Parekh VI, Agarwal SK \& Arnold A. Germline and somatic mutations in cyclin-dependent kinase inhibitor genes CDKN1A, CDKN2B, and CDKN2C in sporadic parathyroid adenomas. Hormones and Cancer 20134 301-307. (https://doi.org/10.1007/s12672-013-0147-9)

62 Au A, McDonald K, Gill A, Sywak M, Diamond T, Conigrave A \& Clifton-Bligh R. PTH mutation with primary hyperparathyroidism and undetectable intact PTH. New England Journal of Medicine 2008 359 1184. (https://doi.org/10.1056/NEJMc0802570)

63 Björklund P, Lindberg D, Åkerström G \& Westin G. Stabilizing mutation of CTNNB1/beta-catenin and protein accumulation analyzed in a large series of parathyroid tumors of Swedish patients. Molecular Cancer 200871

64 Costa-Guda J \& Arnold A. Absence of stabilizing mutations of $\beta$-catenin encoded by CTNNB1 exon 3 in a large series of sporadic parathyroid adenomas. Journal of Clinical Endocrinology and Metabolism 200792 1564-1566. (https://doi.org/10.1210/jc.20062554)

65 Guarnieri V, Baorda F, Battista C, Bisceglia M, Balsamo T, Gruppioni E, Fiorentino M, Muscarella LA, Coco M \& Barbano R. A rare S33C mutation of CTNNB1 encoding $\beta$-catenin in a parathyroid adenoma found in an Italian primary hyperparathyroid cohort.
Endocrine 201241 152-155. (https://doi.org/10.1007/s12020-0119558-y)

66 Starker LF, Fonseca A, Åkerström G, Björklund P, Westin G \& Carling T. Evidence of a stabilizing mutation of $\beta$-catenin encoded by CTNNB1 exon 3 in a large series of sporadic parathyroid adenomas. Endocrine 201242 612-615. (https://doi.org/10.1007/s12020-0129690-3)

67 Björklund P, Åkerström G \& Westin G. An LRP5 receptor with internal deletion in hyperparathyroid tumors with implications for deregulated WNT/ß-catenin signaling. PLoS Medicine 20074 e328.

68 Bjorklund P, Akerstrom G \& Westin G. Accumulation of nonphosphorylated $\beta$-catenin and c-myc in primary and uremic secondary hyperparathyroid tumors. Journal of Clinical Endocrinology and Metabolism 200792 338-344. (https://doi.org/10.1210/jc.20061197)

69 Björklund P, Åkerström G \& Westin G. Activated $\beta$-catenin in the novel human parathyroid tumor cell line sHPT-1. Biochemical and Biophysical Research Communications 2007352 532-536.

70 Lambert D, Eaton CL \& Harrison BJ. Fibroblast growth factors and their receptors in parathyroid disease. World Journal of Surgery 1998 22 520-525. (https://doi.org/10.1007/s002689900429)

71 Segiet OA, Michalski M, Brzozowa-Zasada M, Piecuch A, Żaba M, Helewski K, Gabriel A \& Wojnicz R. Angiogenesis in primary hyperparathyroidism. Annals of Diagnostic Pathology 201519 91-98. (https://doi.org/10.1016/j.anndiagpath.2015.01.002)

72 Asahara T, Bauters C, Zheng LP, Takeshita S, Bunting S, Ferrara N, Symes JF \& Isner JM. Synergistic effect of vascular endothelial growth factor and basic fibroblast growth factor on angiogenesis in vivo. Circulation 199592 365-371. (https://doi.org/10.1161/01. CIR.92.9.365)

73 Schuster N \& Krieglstein K. Mechanisms of TGF- $\beta$-mediated apoptosis. Cell and Tissue Research 2002307 1-14. (https://doi. org/10.1007/s00441-001-0479-6)

74 Tanaka R, Tsushima T, Murakami H, Shizume K \& Obara T. Insulinlike growth factor I receptors and insulin-like growth factor-binding proteins in human parathyroid tumors. World Journal of Surgery 1994 18 635-641. (https://doi.org/10.1007/BF00353784)

75 Segiet OA, Deska M, Mielańczyk Ł, Brzozowa-Zasada M, Buła G, Gawrychowski J \& Wojnicz R. Expression of TRAIL and Fas in primary hyperparathyroidism. Journal of Investigative Surgery 201630 242-246. (https://doi.org/10.1080/08941939.2016.1236159)

76 Corazza N, Kassahn D, Jakob S, Badmann A \& Brunner T. TRAIL-induced apoptosis. Annals of the New York Academy of Sciences 2009 1171 50-58. (https://doi.org/10.1111/j.17496632.2009.04905.x)

77 Michowitz Y, Goldstein E, Roth A, Afek A, Abashidze A, Gal YB Keren G \& George J. The involvement of tumor necrosis factorrelated apoptosis-inducing ligand (TRAIL) in atherosclerosis. Journal of the American College of Cardiology 200545 1018-1024. (https://doi. org/10.1016/j.jacc.2004.12.065)

78 Mori K, Inaba M \& Emoto M. Multifunctional role of TRAIL in atherosclerosis and cardiovascular disease. In Advances in the Diagnosis of Coronary Atherosclerosis. Ed SF Kiraç. Rijek, Croatia: InTech, 2011. (available at: http://cdn.intechweb.org/pdfs/23194.pdf)

79 Stuckey DW \& Shah K. TRAIL on trial: preclinical advances in cancer therapy. Trends in Molecular Medicine 201319 685-694. (https://doi. org/10.1016/j.molmed.2013.08.007)

80 Guicciardi ME \& Gores GJ. Life and death by death receptors. FASEB Journal 200923 1625-1637. (https://doi.org/10.1096/fj.08-111005)

81 Schneider P, Thome M, Burns K, Bodmer J-L, Hofmann K, Kataoka T, Holler N \& Tschopp J. TRAIL receptors 1 (DR4) and 2 (DR5) signal FADD-dependent apoptosis and activate NF-кB. Immunity 19977 831-836. (https://doi.org/10.1016/S1074-7613(00)80401-X)

82 Aló PL, Visca P, Mazzaferro S, Serpieri DE, Mangoni A, Botti C, Monaco S, Carboni M, Zaraca F \& Trombetta G. Immunohistochemical study of fatty acid synthase, Ki67, http://www.endocrineconnections.org

https://doi.org/10.1530/EC-17-0283
(C) 2018 The authors

Published by Bioscientifica Ltd
This work is licensed under a Creative Commons Attribution-NonCommercial 4.0 International License. 
proliferating cell nuclear antigen, and p53 expression in hyperplastic parathyroids. Annals of Diagnostic Pathology 19993 287-293.

83 Erickson LA, Jin L, Wollan P, Thompson GB, Van Heerden JA \& Lloyd RV. Parathyroid hyperplasia, adenomas, and carcinomas: differential expression of p27Kip1 protein. American Journal of Surgical Pathology 199923 288-295. (https://doi.org/10.1097/00000478199903000-00007)

84 Morrison C, Farrar W, Kneile J, Williams N, Liu-Stratton Y, Bakaletz A, Aldred MA \& Eng C. Molecular classification of parathyroid neoplasia by gene expression profiling. American Journal of Pathology 2004165 565-576. (https://doi.org/10.1016/S0002-9440(10)63321-4)

85 Velázquez-Fernández D, Laurell C, Saqui-Salces M, Pantoja JP, Candanedo-Gonzalez F, Reza-Albarrán A, Gamboa-Dominguez A \& Herrera MF. Differential RNA expression profile by cDNA microarray in sporadic primary hyperparathyroidism (pHPT): primary parathyroid hyperplasia versus adenoma. World Journal of Surgery 200630 705-713.
86 Carling T. Molecular pathology of parathyroid tumors. Trends in Endocrinology and Metabolism 200112 53-58. (https://doi. org/10.1016/S1043-2760(00)00345-3)

87 Chan S-H \& Wang L-H. Regulation of cancer metastasis by microRNAs. Journal of Biomedical Science 201522 1. (https://doi. org/10.1186/s12929-014-0106-y)

88 Verdelli C, Forno I, Vaira V \& Corbetta S. MicroRNA deregulation in parathyroid tumours suggests an embryonic signature. Journal of Endocrinological Investigation 201538 383-388. (https://doi. org/10.1007/s40618-014-0234-y)

89 Corbetta S, Vaira V, Guarnieri V, Scillitani A, Eller-Vainicher C, Ferrero S, Vicentini L, Chiodini I, Bisceglia M \& Beck-Peccoz P. Differential expression of microRNAs in human parathyroid carcinomas compared with normal parathyroid tissue. EndocrineRelated Cancer 201017 135-146. (https://doi.org/10.1677/ERC-090134)

Received in final form 20 December 2017

Accepted 12 January 2018

Accepted Preprint published online 12 January 2018 http://www.endocrineconnections.org https://doi.org/10.1530/EC-17-0283
() 2018 The authors Published by Bioscientifica Ltd

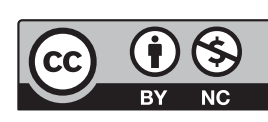

This work is licensed under a Creative Commons Attribution-NonCommercial 4.0 International License. 